\title{
Serum ghrelin level is associated with cardiovascular risk score
}

\author{
DANA POP ${ }^{1}$, P. $^{\text {PETER }}{ }^{1}$, ALEXANDRA DĂDÂRLAT $^{1}$, ADELA SITAR-TĂUT $^{1}$, D. ZDRENGHEA ${ }^{1}$ \\ 1،"Iuliu Hațieganu" University of Medicine and Pharmacy, Cluj-Napoca
}

\begin{abstract}
Ghrelin, a newly discovered bioactive peptide, was originally reported to induce growth hormone release. Recent studies have shown beneficial hemodynamic effects of ghrelin in the cardiovascular system to support the wide distribution of its receptors in cardiovascular tissues. The aim of the study was to determine whether cardiovascular risk factors influence plasma ghrelin levels.

Methods. We evaluated in the Rehabilitation Hospital Cluj-Napoca, Cardiology - Department 88 consecutive subjects, $65(73.86 \%)$ being women, with mean age $61.7 \pm 10.33$ years. We assessed the presence of cardiovascular risk factors (obesity, arterial hypertension, diabetes mellitus, metabolic syndrome, smoking and lipid fractions). Plasma ghrelin levels were determined with a commercial ELISA kit (pg/ml).

Results. After the evaluation of cardiovascular risk factors, we found no statistically significant difference between ghrelin levels in the patients with vs those without cardiovascular risk factors ( $p>0.05$ ). A negative correlation was found between ghrelin levels and age, $r=-0.32(p<0.05)$. Using the HeartScore Internet tool we calculated the cardiovascular risk for each patient according to the risk score system (SCORE) for high cardiovascular risk countries. Statistically, the risk of fatal cardiovascular events in the next 10 years was indirectly correlated with the ghrelin levels in each patient - correlation between ghrelin levels and SCORE system $\mathrm{r}=-0.25, \mathrm{p}=0.015$. In conclusion, low serum ghrelin concentrations are associated with an increased global cardiovascular risk, calculated based on the European SCORE scale. However, we could not demonstrate a direct relationship between any of the major risk factors and ghrelin.
\end{abstract}

Key words: ghrelin, cardiovascular risk factors, SCORE.

\section{INTRODUCTION}

Despite all the new complex and effective medical treatments, the incidence of cardiovascular disease is constantly rising. Thus, cardiovascular disease remains the number one killer of men and women in Europe. Traditional and non-traditional ("new biomarkers") cardiovascular risk factors are in close association with this high worldwide incidence of cardiovascular diseases. The most studied "new biomarkers" are: C-reactive protein high sensibility, homocysteine, phospholipase $\mathrm{A}_{2}$, adipocytokines, some coagulation factors, metalloproteinase. Lately, the researchers' attention has been drawn to a new biomarker: ghrelin.

Ghrelin is a bioactive peptide secreted by the oxyntic mucosa of the stomach with important growth hormone $(\mathrm{GH})$ releasing effects. It is pulsatively released into the plasma and reaches circulating levels of $700 \mathrm{pg} / \mathrm{ml}$ when fasting and approximately $300 \mathrm{pg} / \mathrm{ml}$ after food ingestion [1]. Two major forms of ghrelin can be found in the plasma and tissues: nonacylated ghrelin, representing $80-90 \%$ of the circulating ghrelin, and des-acyl ghrelin, which undergoes a posttranslational modi- fication under the influence of ghrelin O-acyl transferase (GOAT) on its third serine [2].

Recent studies have shown that, while desacyl ghrelin plays an essential part in stimulating the growth hormone $(\mathrm{GH})$ release and regulating glucose and energy homeostasis, non-acylated ghrelin is involved in the modulation of cardiovascular functions as well as in the fat and glucose metabolism [3].

The aim of the study was to determine whether plasma ghrelin levels influence cardiovascular risk factors and global cardiovascular risk score (SCORE assessment).

\section{METHODS}

'The study included 88 consecutive patients admitted in the Cardiology Department of the Rehabilitation Hospital, Cluj-Napoca, Romania. The mean age of the subjects was $61.7 \pm 10.33$ years. Blood pressure was measured according to standard protocol as the mean of two readings after the participant was at rest for $5 \mathrm{~min}$ in a sitting position. Blood samples $(10 \mathrm{ml})$ were obtained by 
venipuncture according to the standard Lipid Research Clinics protocol [4]. Low-density lipoprotein cholesterol (LDL-C) was estimated using the Friedewald formula [5]. Plasma glucose levels were measured by the glucose oxidase method [6]. Abdominal obesity was defined by waist circumference men $\geq 102 \mathrm{~cm}$ and women $\geq 88 \mathrm{~cm}$ [7]. Overweight was defined as a body mass index (BMI) from 25 to $29.9 \mathrm{~kg} /(\mathrm{m})^{2}$ and obesity as a $\mathrm{BMI} \geq 30 \mathrm{~kg} /(\mathrm{m})^{2}$ [7]. Plasma ghrelin levels were determined with a commercial ELISA kit and the results were measured in $\mathrm{pg} / \mathrm{ml}$. Normal ghrelin levels found in subjects without any pathology range between 33.72 and $67.44 \mathrm{pg} / \mathrm{ml}$.

We calculated the cardiovascular risk for each patient according to the risk score system (SCORE) for high cardiovascular risk countries by using the HeartScore Internet tool: https:/escol. escardio.org/Heartscore/calc.aspx?model=europehi gh [8]. We took into consideration: age, gender, total cholesterol, systolic blood pressure, smoking or non-smoking habits.

Statistical analysis was carried out using the SPSS for Windows ( $\mathrm{v}$ 16.0, IBM Corporation, Armonk, NY, USA) and MedCalc (v 10.3.0.0, MedCalc Software, Ostend, Belgium) software programs. The Kolmogorov-Smirnov test was used to assess the normal distribution of continuous numerical variables. The results were presented as number and percentages for qualitative variables and, for the quantitative ones, as mean \pm standard deviation or median values. The analysis of the differences between qualitative variables was performed using the $\chi^{2}$ test. For comparison of numeric variables, Student T or Mann-Whitney test were used. Pearson, respectively Spearman correlation coefficients were calculated. A value of $\mathrm{p}<0.05$ was considered statistically significant.

The selected patients were informed about the study protocol and gave their signed informed consent. The study was carried out in accordance with The Code of Ethics of the World Medical Association (Declaration of Helsinki) for experiments involving humans.

\section{RESULTS}

The demographic and clinical features of the participants are summarized in Table 1.

After the cardiovascular risk factors (hypertension, total cholesterol, LDL-cholesterol, triglycerides, HDL-cholesterol, BMI, glycemia, metabolic syndrome) were evaluated for all 88 patients, we found no statistically significant difference between ghrelin levels in the patients with and those without cardiovascular risk factors (nonparametric tests Mann Whitney U) (p>0.05) - Table 2, Figure 1.

Table 1

Age-Adjusted Mean_SD or Prevalence of Risk Factors

\begin{tabular}{|c|c|c|c|c|}
\hline Variables & $\begin{array}{l}\text { All patients } \\
88 \text { patients }\end{array}$ & $\begin{array}{c}\text { Women } \\
65 \text { patients }\end{array}$ & $\begin{array}{c}\text { Males } \\
23 \text { patients }\end{array}$ & $\mathrm{p}$ \\
\hline Age (years) & $61.7 \pm 10.33$ & $60.43 \pm 10.2$ & $65.3 \pm 10$ & 0.05 \\
\hline Smokers (\%) & 17 & 16 & 22 & 0.05 \\
\hline Metabolic syndrome (\%) & 74 & 73 & 79 & 0.77 \\
\hline Total Cholesterol (mg/dl) & $212.96 \pm 51.95$ & $221.97 \pm 47.21$ & $187.52 \pm 57.24$ & 0.01 \\
\hline LDL-Cholesterol (mg/dl) & $137.034 \pm 40.73$ & $142.82 \pm 36.99$ & $120.70 \pm 46.92$ & 0.02 \\
\hline HDL-Cholesterol (mg/dl) & $42.81 \pm 9.045$ & $38.13 \pm 8.93$ & $44.48 \pm 8.55$ & 0.01 \\
\hline Triglycerides (mg/dl) & $154.11 \pm 69.35$ & $157.82 \pm 74.02$ & $143.65 \pm 54.10$ & 0.4 \\
\hline Hypertension (\%) & 80 & 80 & 79 & 0.84 \\
\hline Diabetes $(\%)$ & 28 & 23 & 40 & 0.19 \\
\hline Waist circumference $(\mathrm{cm})$ & $98.57 \pm 10.75$ & $96.71 \pm 10.77$ & $103.87 \pm 8.98$ & 0.01 \\
\hline Body mass index $\left(\mathrm{kg} / \mathrm{m}^{2}\right)$ & $29.051 \pm 4.35$ & $29.11 \pm 4.57$ & $28.89 \pm 3.76$ & 0.84 \\
\hline Ghrelin (pg/ml) & $40.11 \pm 19.47$ & $41.90 \pm 21.46$ & $35.07 \pm 11.15$ & 0.15 \\
\hline
\end{tabular}

Table 2

Relationship between ghrelin level and cardiovascular risk factors

\begin{tabular}{|c|c|c|c|c|c|c|c|c|c|}
\hline & Statistical variables & Age & BMI & Waist circumference & Glycemia & Total-Co & LDL-Co & HDL-Co & TG \\
\hline \multirow{4}{*}{ 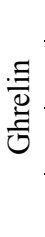 } & $\mathrm{r}$ & -0.32 & 0.19 & 0.16 & 0.09 & -0.01 & -0.05 & 0.14 & 0.01 \\
\hline & $\inf$ & -0.50 & -0.03 & -0.05 & -0.12 & -0.22 & -0.26 & -0.07 & -0.20 \\
\hline & sup & -0.12 & 0.38 & 0.36 & 0.30 & 0.20 & 0.16 & 0.34 & 0.22 \\
\hline & $\mathrm{p}$ & $<0.005$ & 0.08 & 0.14 & 0.38 & 0.89 & 0.65 & 0.18 & 0.95 \\
\hline
\end{tabular}

$\overline{\text { Total }}-\mathrm{Co}=$ Total Cholesterol, LDL-Co $=\frac{\mathrm{LDL}-\mathrm{Cholesterol,} \mathrm{HDL-Co}=\text { HDL-Cholesterol, }}{\mathrm{TG}}=\frac{0}{\mathrm{~L}} \mathrm{Triglycerides}$. 


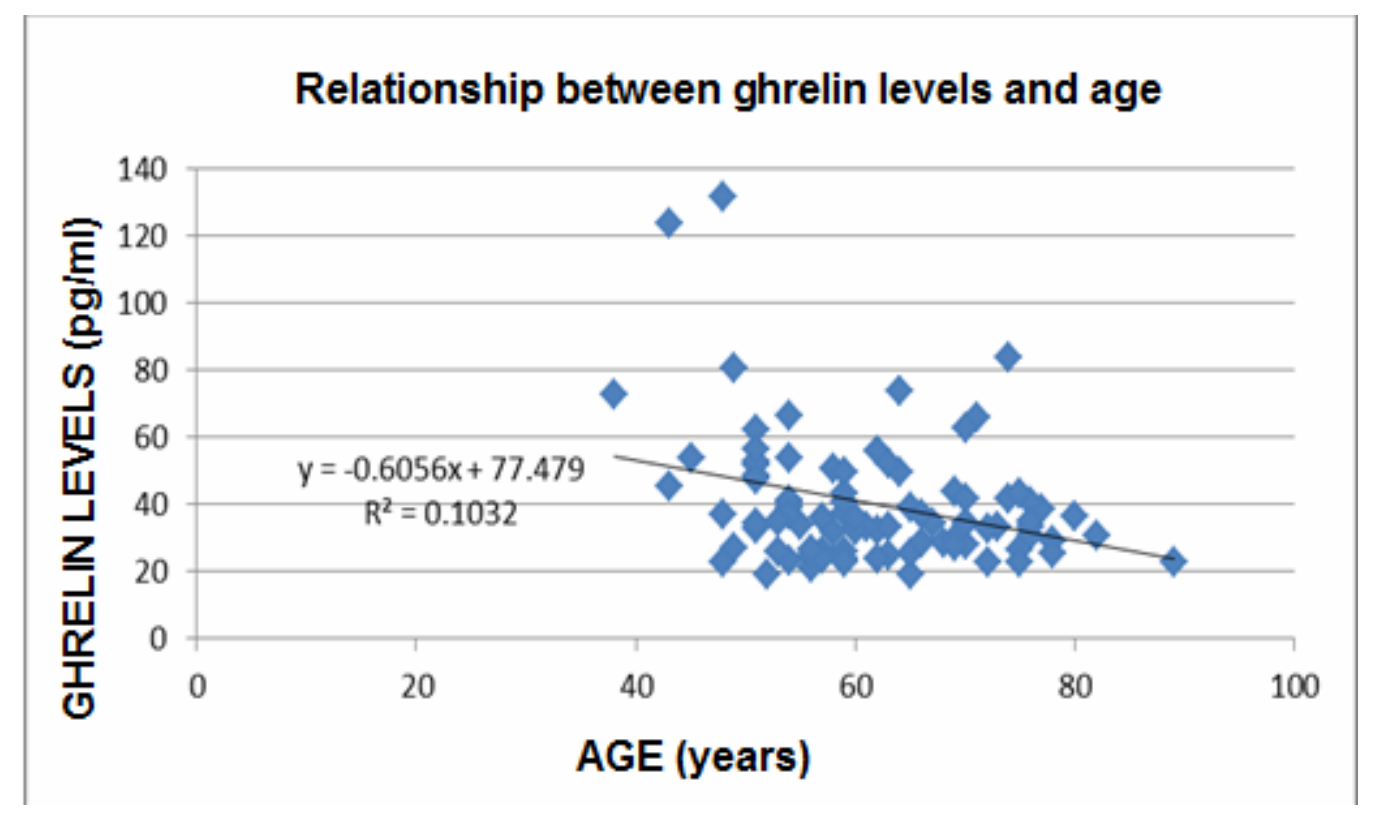

Fig. 1. Relationship between ghrelin levels and age.

Ghrelin levels were negatively corelated with age, $r=-0.32(p<0.05)$.

The mean concentration of ghrelin in patients with hypertension was $40.40 \pm 21.12 \mathrm{pg} / \mathrm{ml}$ and $39 \pm 11 . \mathrm{pg} / \mathrm{ml}$ in those without hypertension. According to Mann Whitney U test, ghrelin levels were not significantly different in patients with hypertension from those without hypertension. The average value of ghrelin found in smokers was $47.7 \pm 25.8 \mathrm{pg} / \mathrm{ml}$, and was not significantly different from the average value in non smokers (Mann Whitney $U$ test, $\mathrm{p}=0.07$ ). We recorded mean values of ghrelin of $43.3 \pm 22.3 \mathrm{pg} / \mathrm{ml}$ in obese subjects and $38.4 \pm 17.6 \mathrm{pg} / \mathrm{ml}$ in those without obesity. We found no statistically significant difference between ghrelin levels in the patients with and those without metabolic syndrome $(39.32 \pm 18.49$ vs $42.35 \pm 22.34 \mathrm{pg} / \mathrm{ml}(\mathrm{p}=0.95)$ Also, ghrelin values were not significantly different in patients with diabetes compared with those without diabetes $(36.13 \pm 16.64$ vs $41.61 \pm 20.36 \mathrm{pg} / \mathrm{ml}$, $\mathrm{p}=0.8)$.

We calculated the cardiovascular risk for each patient according to the risk score system (SCORE) for high cardiovascular risk countries by using the HeartScore Internet tool: https://escol. escardio.org/Heartscore/calc.aspx?model=europehi gh [8]. We took into consideration: age, gender, total cholesterol, systolic blood pressure, smoking or non-smoking habits. We got the risk of cardiovascular events within 10 years (in \%), that is a mean value of $4.28 \pm 3.57 \%$. Statistically, the risk of fatal cardiovascular events in the next 10 years was indirectly correlated with the ghrelin levels in each patient. Thus, we recorded the presence of a statistically significant correlation between ghrelin levels and the SCORE system $(\mathrm{r}=-0.25, \mathrm{p}=0.015)-$ Figure 2. When divided according to gender, the statistical significance became irrelevant.

\section{DISCUSSION}

Plasma ghrelin levels show a marked variation throughout the day, due to the physiological role of this hormone in initiating food. Thus, ghrelin concentration increases by approximately $78 \%$ with 1-2 hours before eating and decreases again to baseline values within 1 hour after the meal. However, the value obtained in a single morning determination seems to correlate very well with the 24-hour integrated value (area under the curve) and thus it can serve as a "surrogate" for the total concentration of hormone [9].

Although new relevant data regarding the cardiovascular effects of ghrelin began to appear, the relationship between plasma ghrelin levels and cardiovascular pathology, especially atherosclerosis and coronary heart disease, remains incompletely elucidated. For example, Pöykkö et al. showed that serum levels of ghrelin are positively associated with atherosclerosis in men, but not in women [10]. On the other hand, the studies conducted by Zhang $\mathrm{M}$ et al. and Yang $\mathrm{D}$ et al. have reported that low levels of ghrelin are associated with the severity and complexity of coronary atherosclerotic lesions [11-13]. 


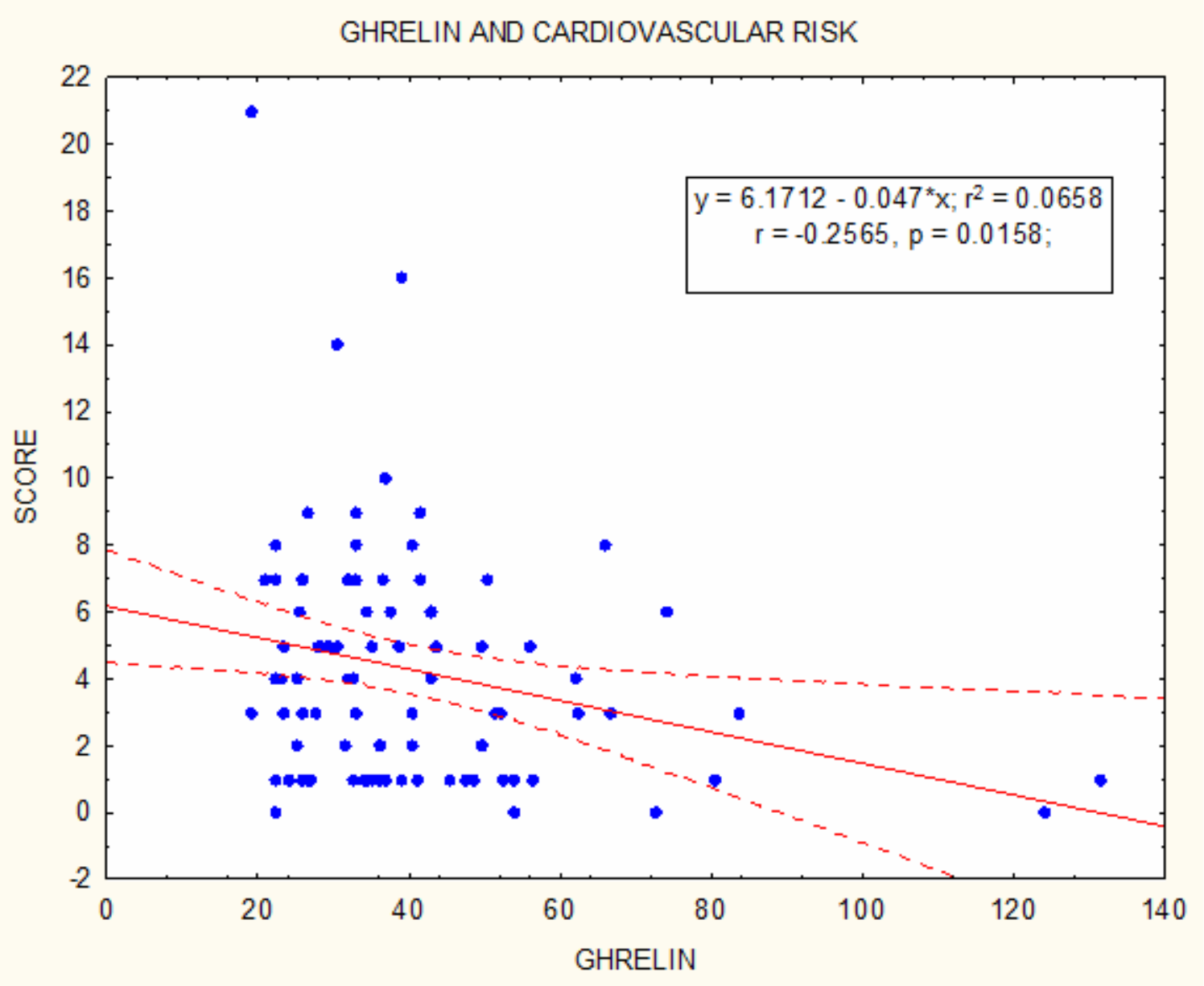

Fig. 2. Ghrelin and cardiovascular risk.

There are few studies regarding the relation between ghrelin and cardiovascular risk factors. Our analysis did not reveal any association between the major cardiovascular risk factors and ghrelin values, although low ghrelin levels were correlated with high total cardiovascular risk. On the other hand, it is hard to evaluate the exact relation between ghrelin and a specific risk factor, as most patients present several risk factors and one cannot determine precisely to what extent they interact or the cumulative effect they have with age. A study conducted on a group of teenagers divided the subjects according to the number of cardiovascular risk factors $(0,1,2,3$ or more) [14]. It proved that ghrelin values declined with the increase in the number of cardiovascular risk factors in one individual, but only in case of male subjects; in females, the levels remained rather balanced [14]. A recent study demonstrated the possibility of using ghrelin as biomarker in cardiovascular events risk prognosis models [15].

Low plasma ghrelin levels were associated with obesity [16]; the assertion was in agreement with our study that showed a negative correlation of ghrelin with waist circumference and BMI in subjects without ischemic heart disease. Latest studies suggested that des-acyl ghrelin secretion in obese patients might be inhibited by hyperinsulinemia and hyperleptinemia $[17,18]$.

In animal subjects, low circulating ghrelin was found to be in association with different insulin-resistant states, including type 2 diabetes [19]. Early studies on rats revealed reduced ghrelin plasma levels in the development of peripheral insulin resistance [19].

As it is well known, metabolic syndrome and diabetes type 2 are important cardiovascular risk factors. Low levels of ghrelin are associated with an increased number of metabolic syndrome symptoms [20].

Although there is data substantiating ghrelin involvement in hypertension regulation, the precise mechanism is still unknown. In fact, ghrelin seems to suppress sympathetic activity, stimulate nitric oxide, reduce oxidative stress and inhibit endothelial cells apoptosis [21]. So, hypertensive patients should have low circulating ghrelin levels [21]. 
Ghrelin gene (located on chromosome 3) mutations seem to induce low ghrelin levels, which may lead to hypertension development [22]. On the contrary, earlier studies have disagreed with correlating ghrelin with hypertension, advocating only an association with left ventricular hypertrophy [23]. In our study, ghrelin levels were not correlated with hypertension and neither with plasma lipid fractions. Undoubtedly, our study had certain limitations such as the small size of the patient cohort and its heterogeneity.

Our study showed a negative correlation between the global SCORE cardiovascular risk and serum levels of ghrelin. We took into consideration: age, gender, total cholesterol, systolic blood pressure, smoking or non-smoking habits. We got the risk of cardiovascular events within 10 years (in \%), that is a mean value of $4.28 \pm 3.57 \%$. Statistically, the risk of fatal cardiovascular events in the next 10 years was indirectly correlated with the ghrelin levels in each patient. Thus, we recorded the presence of a statistically significant correlation between ghrelin levels and SCORE system. However, ghrelin levels variations were not associated with the presence of any of the major cardiovascular risk factors. A recent study describes the possibility of using ghrelin as a biomarker for predicting the risk of $\mathrm{CV}$ events [15]. In order to justify the use of ghrelin in clinical practice, it is necessary to demonstrate an additional benefit in predicting cardiovascular risk. Even though, ghrelin values are independently associated with $\mathrm{CV}$ pathology, more data is required.

Several limitations of this study should be noted: a relatively small number of patients, the absence of a control group, the lack of randomization and the heterogeneity of the studied group. Without a control group, it is difficult to assess the actual effects of $\mathrm{CV}$ risk factors on ghrelin levels. The high number of female subjects contained in the lot and the lack of randomization could be sources of error, as long as the variations of ghrelin concentrations in men versus women related to various pathologies are not fully known.

Finally, the heterogeneity of the lot does not allow a targeted analysis; most of the patients had several CV risk factors, which could interact one with each other. Thus, it is difficult to assess how these complex interactions influence serum ghrelin levels.

\section{CONCLUSION}

Lower serum ghrelin concentration is associated with an increased global cardiovascular global risk score (SCORE assessment), calculated based on the European scale. However, we failed to demonstrate a link between any of the major risk factors and ghrelin.

Premize. Dacă inițial s-a demonstrat că grelina, un nou peptid bioactiv, determină eliberarea de hormon de creştere, studii mai recente au arătat că acesta are efecte benefice asupra sistemului cardiovascular. Scopul prezentului studiu a fost reprezentat de evaluarea influenței factorilor de risc cardiovascular asupra nivelurilor grelinei.

Metodă. Au fost evaluați în cadrul Spitalului de Recuperare Cluj-Napoca, Secția Cardiologie, 88 de pacienți, 65 (73.86\%) femei, cu vârsta medie $61.7 \pm 10.33$ anievaluându-se prezența factorilor de risc cardiovascular (obezitate, hipertensiune arterială, diabet zaharat, sindrom metabolic, fumat şi fracțiuni lipidice). Nivelul seric al grelinei $(\mathrm{pg} / \mathrm{ml})$ a fost determinat prin metoda ELISA.

Rezultate. După evaluarea factorilor de risc cardiovascular, nu au fost innegistrate diferențe semnificative din punct de vedere statistic intre nivelele serice ale grelinei la pacienții cu şi cei fără factori de risc cardiovascular $(p>0.05)$. S-a identificat o corelație negativă între nivelul grelinei şi vârstă $r=$ -0.32 ( $p$ <0.05). Riscul cardiovascular al fiecărui pacient-SCORE, a fost calculat, utilizând HeartScore Internet tool (grila SCORE pentru țările cu risc cardiovascular crescut). Statistic, riscul unui eveniment cardiovascular fatal in următorii 10 ani s-a corelat, pentru fiecare pacient, indirect cu nivelul seric al grelinei $-r=-0.25, p=0.015$. In concluzie, deşi nivele serice scăzute ale grelinei se asociază cu un risc SCORE cardiovascular global înalt, nu s-a identificat o relație directă între factorii de risc cardiovascular şi grelină. 
Corresponding author: Peter Paul Rehabilitation Hospital, Cardiology Department, Cluj-Napoca, 46-50 Viilor Street, postal code 400437, Phone: 0264207021 E-mail:ppaul_eks@yahoo.com

Conflicts of interest: none.

\section{REFERENCES}

1. GARCÍA EA, KORBONITS M. Ghrelin and cardiovascular health. Curr Opin Pharmacol. 2006; 6 (2):142-7.

2. TESAURO M, SCHINZARI F, CARAMANTI M, LAURO R, CARDILLO C. Metabolic and cardiovascular effects of ghrelin. Int J Pept. 2010; 6:62-70.

3. BROGLIO F, PRODAM F, ME E, RIGANTI F, LUCATELlO B, GRANATA R, BENSO A, MUCCIOLI G, GHIGO E. Ghrelin: endocrine, metabolic and cardiovascular actions. J Endocrinol Invest. 2005; 28(5 Suppl):23-5.

4. The Lipid Research Clinics Coronary Primary Prevention Trial Results I. Reduction in Incidence of Coronary Heart Disease. JAMA. 1984; 251:351-64.

5. FRIEDEWALD WT, LEVY RI, FREDRICKSON DS. Estimation of the concentration of low-density lipoprotein cholesterol in plasma, without use of the preparative centrifuge. Clin Chem. 1972; 18:499-500.

6. LOTT JA, TURNER K. Evaluation of Trinder's glucose oxidase method for measuring glucose in serum and urine. Clin Chem. 1975; 21:1754-60.

7. ESH/ESC TASK FORCE FOR THE MANAGEMENT OF ARTERIAL HYPERTENSION. 2013. Practice guidelines for the management of arterial hypertension of the European Society of Hypertension (ESH) and the European Society of Cardiology (ESC): ESH/ESC Task Force for the Management of Arterial Hypertension. J Hypertens. 2013; 31(10):1925-38.

8. https://escol.escardio.org/Heartscore/calc.aspx?model=europehigh.

9. CUMMINGS DE, PURNELL JQ, FRAYO RS, SCHMIDOVA K, WISSE BE, WEIGLE DS. A preprandial rise in plasma ghrelin levels suggests a role in meal initiation in humans. Diabetes. 2001; 50(8):1714-9.

10. POYKKO SM, KELLOKOSKI E, HORKKO S, KAUMA H, KESANIEMI YA, UKKOLA O. Low plasma ghrelin is associated with insulin resistance, hypertension, and the prevalence of type 2 diabetes. Diabetes. 2003; 52(10):2546-53.

11. ZHANG M, FANG WY, YUAN F, QU XK, LIU H, XU YJ, CHEN H, YU YF, SHEN Y, ZHENG ZC. Plasma ghrelin levels are closely associated with severity and morphology of angiographically-detected coronary atherosclerosis in Chinese patients with diabetes mellitus. Acta Pharmacol Sin. 2012; 33(4):452-8.

12. ZHANG M, FANG W, YUAN F, QU X, LIU H, CHEN H, YU Y, ;ZHENG Z, SHEN Y. Plasma ghrelin levels are closely associated with stenosis severity and morphology of angiographically-detected coronary atherosclerosis in patients with coronary artery disease. Int J Cardiol 2011; 151(1):122-3.

13. YANG D, LIU Z, LUO Q. Plasma ghrelin and pro-inflammatory markers in patients with obstructive sleep apnea and stable coronary heart disease. Med Sci Monit2013; 19:251-6.

14. YOSHINAGA M, TAKAHASHI H, SHINOMIYA M, MIYAZAKI A, KURIBAYASHI N, ICHIDA F. Impact of having one cardiovascular risk factor on other cardiovascular risk factor levels in adolescents. J Atheroscler Thromb. 2010; 17(11):1167-75.

15. YANO Y, NAKAZATO M, TOSHINAI K, INOKUCHI T, MATSUDA S, HIDAKA T, HAYAKAWA M, KANGAWA K, SHIMADA K, KARIO K. Circulating des-acyl ghrelin improves cardiovascular risk prediction in older hypertensive patients. Am J Hypertens 2014; 27(5):727-33.

16. HAMED EA, ZAKARY MM, AHMED NS, GAMAL RM. Circulating leptin and insulin in obese patients with and without type 2 diabetes mellitus: relation to ghrelin and oxidative stress. Diabetes Res Clin Pract. 2011; 94(3):434-41.

17. RODRÍGUEZ A, GÓMEZ-AMBROSI J, CATALÁN V, BECERRIL S, SÁINZ N, GIL MJ, SILVA C, SALVADOR J, BARBA J, COLINA I, FRÜHBECK G. Association of plasma acylated ghrelin with blood pressure and left ventricular mass in patients with metabolic syndrome. J Hypertens. 2010; 28(3):560-7.

18. UKKOLA O. Ghrelin and metabolic disorders. Curr Protein Pept Sci. 2009; 10: 2-7.

19. VESTERGAARD ET, GORMSEN LC, JESSEN N, LUND S, HANSEN TK, MOLLER N, JORGENSEN JO. Ghrelin infusion in humans induces acute insulin resistance and lipolysis independent of growth hormone signaling. Diabetes 2008; 57(12): 3205-10.

20. ZHANG G, YIN X, QI Y, PENDYALA L, CHEN J, HOU D , TANG C. Ghrelin and cardiovascular diseases. Curr Cardiol Rev. 2010; 6(1):62-70.

21. POYKKO SM, KELLOKOSKI E, HORKKO S, KAUMA H, KESÄNIEMI YA, UKKOLA O. Low plasma ghrelin is associated with insulin resistance, hypertension, and the prevalence of type 2 diabetes. Diabetes 2003; 52: 2546-53.

22. POYKKO S, UKKOLA O, KAUMA H, SAVOLAINEN MJ, KESANIEMI YA. Ghrelin Arg51Gln mutation is a risk factor for type 2 diabetes and hypertension in a random sample of middle-aged subjects. Diabetologia 2003; 46: 455-8.

23. UKKOLA O, PÄÄKKÖ T, KESÄNIEMI YA. Ghrelin and its promoter variant associated with cardiac hypertrophy. J Hum Hypertens. 2012; 26(7):452-7. 